\title{
HUBUNGAN PENGETAHUAN, STATUS EKONOMI, PERAN PETUGAS KESEHATAN DAN PERAN KELUARGA TERHADAP VAKSINASI HPV (HUMAN PAPILLOMA VIRUS) DI KLINIK DARA JINGGA KOTA JAMBI TAHUN 2017
}

\author{
Nia Nurzia ${ }^{1}$
}

\begin{abstract}
Abnormal cervical is still in high levels of which marked by the outbreak of the Human Papilloma Virus, It is not offset by the use of vaccination (HPV) Human Papilloma Virus which as the primary prevention of the spread of Human Papilloma Virus . recorded in Dara Jingga clinic in 2015, there were 226 people in the state of the cervix abnormal while those who making vaccination extremely low at only 40 people. Likewise, in 2016 there were 301 people in a state of abnormal cervical and vaccinated only 16 people. Based on it, this research is the research which aimed to determine the relationship between knowledge, economic status, family role and the role of health personnel against the Human Papilloma Virus vaccination in Dara Jingga Clinic Jambi City. This research is descriptive analytic with cross sectional design, the data collected through questionnaires, with a population was 321 people. using acidental sampling technique with sample was 32 people, research has been conducted on 22 to 24 August 2016 using univariate and bivariate analysis assisted by a computer program. The results of the univariate analysis of vaccination picture were 10 respondents (31.3\%) take advantage of HPV vaccination and 22 respondents $(68,8 \%)$ did not take advantage of the HPV vaccination, an overview of knowledge were five respondents $(15,6 \%)$ have sufficient knowledge, 15 respondents $(46,9 \%)$ had a good knowledge, 12 respondents $(37,5 \%)$ had poor knowledge, an overview of economic status, 13 respondents $(40,6 \%)$ had high economic status and 19 respondents $(59,4 \%)$ have lower economic status, description of the role of health workers 13 respondents $(40,6 \%)$ have a good role of health personnel and 19 respondents $(59,4 \%)$ has the role of health personnel is not good. Overview of the role of the family, 11 respondents $(34,4 \%)$ has the role of a good family and 21 respondents $(65,6 \%)$ had a family roles goodles. the result of these studies show a relationship between the mother's knowledge by vaccination with HPV (Human Papilloma Virus ) with a p value of 0,035, the relationship between economic status with vaccination HPV (Human Papilloma Virus with p value 0,002, their relationship with the role of HPV vaccination of health workers with $p$ value 0,002 , their relationship with the family role of $H P V$ vaccination with a $p$ value of 0,004 .
\end{abstract}

Keywords: Knowledge, Economic Status, Role of health personnel, Role of Family,HPV Vaccination (Human Papilloma Virus)

\section{PENDAHULUAN}

Kesehatan repoduksi adalah keadaan sejahtera fisik, mental dan sosial secara utuh yang tidak sematamata bebas dari penyakit atau

\footnotetext{
${ }^{1}$ Universitas Adiwangsa Jambi
}

kecacatan dalam semua hal yang berkaitan dengan sistem reproduksi serta fungsi dan prosesnya (Kumalasari, 2012).

Gangguan sistem reproduksi pada wanita merupakan ketidak normalan yang terdapat pada organ-

Hubungan Pengetahuan, Status Ekonomi, Peran Petugas Kesehatan Dan Peran Keluarga Terhadap Vaksinasi Hpv (Human Papilloma Virus) Di Klinik Dara Jingga Kota Jambi Tahun 2017 
organ reproduksi salah satunya kanker serviks. Kanker serviks merupakan sebuah tumor ganas yang tumbuh di dalam serviks yaitu bagian terendah dari rahim yang menempel pada puncak vagina (Aminati, 2013).

Penyebab yang mendominasi terjadinya kanker serviks dengan prevalensi di dunia 99,7\% adalah HPV (Human Papilloma Virus). Setiap orang yang telah berhubungan seksual memiliki potensi untuk terkena virus HPV (Human Papilloma Virus) (Savitri, 2015).

Ditemukannya vaksin baru yang melawan virus HPV (Human Papilloma Virus) atau virus yang menyebabkan kanker serviks memberikan angin segar bagi para wanita. Vaksin terhadap virus HPV (Human Papilloma Virus) telah diteliti terbukti efektif mencegah sekitar 70-90\% kemungkinan kanker serviks. Vaksin tersebut diharapkan dapat mengurangi jumlah pengidap kanker serviks dan bisa menyelamatkan nyawa mereka (Tilong, 2012).

Apabila semua wanita divaksinasi, maka ada potensi bahwa jumlah kematian akibat kanker serviks di seluruh dunia turun sebanyak dua pertiganya. Vaksinasi dapat mengurangi biaya kesehatan, biopsi, maupun tindakan karena dapat mencegah kanker serviks sehingga juga mengurangi kecemasan mereka bila hasil pap smear tes mereka abnormal, atau jika sakit harus menjalani bermacam-macam pengobatan (Tilong, 2012).

Kanker serviks merupakan penyakit dengan prevalensi tertinggi di Indonesia, setiap tahunnya ada sekitar 15 ribu kasus baru kanker serviks. (World Health Organization) menempatkan Indonesia sebagai negara dengan jumlah penderita kanker serviks terbanyak di dunia.
Kanker serviks juga menjadi peringkat pertama pembunuh wanita di Indonesia (Kemenkes RI, 2015).

Berdasarkan data dari YKI (Yayasan Kanker Indonesia) pada tahun 2014 angka prevalensi kanker seviks yang terjadi di Propinsi Jambi adalah sebanyak 1.729 kasus dan merupakan urutan ke sembilan dari seluruh Propinsi yang ada di Indonesia.

Berdasarkan dari hasil survei awal yang dilakukan di Klinik Dara Jingga kota Jambi pada tanggal 18 September 2017 bahwa, wanita yang telah memeriksakan diri pada tahun 2014 adalah dari 286 orang, hasil pemeriksaannya dalam keadaan normal sangat sedikit yaitu berjumlah 20 orang atau $(6,9 \%)$, sedangkan pada tahun 2015 yang dalam keadaan abnormal sangat besar yaitu berjumlah 226 orang atau $(79,02 \%)$ hal ini tidak sebanding dengan tingkat penggunaan vaksin HPV (Human Papilloma Virus) yaitu berjumlah 40 orang atau 13,9\%). Pada tahun 2016 adalah dari 321 orang, hasil pemeriksaannya dalam keadaan normal menurun menjadi 4 orang atau $(1,24 \%)$, sedangkan yang dalam keadaan abnormal meningkat menjadi 301 orang atau $(93,7 \%)$ hal ini tidak sebanding dengan tingkat penggunaan vaksin HPV (Human Papilloma Virus) yang bertujuan untuk mencegah keadaan abnormal pada serviks/kanker serviks yang hanya berjumlah 16 orang atau $(4,98 \%)$.

Dari data diatas penulis sangat tertarik ingin melakukan penelitian untuk mengetahui dan mempelajari hal yang mempengaruhi perilaku kesehatan terhadap vaksinasi Human Papilloma Virus, dimana diketahui masih rendahnya tingkat penggunaan vaksin HPV (Human Papilloma Virus) yang bertujuan untuk mencegah terinfeksinya Human 
Papilloma Virus yang dapat mengakibatkan kanker serviks, sedangkan tingkat kejadian kanker serviks sangat tinggi yang merupakan penyebab kematian yang tinggi di Indonesia.

Menurut teori Green dalam Notoadmodjo menyatakan bahwa ada 3 faktor yang menentukan atau membentuk seorang dalam berperilaku kesehatan yaitu, faktor Presdisposisi, faktor pemungkin, faktor penguat. Faktor Presdisposisi yaitu faktor yang dapat mempermudah atau mempredisposisi terjadinya perilaku seseorang, yang terdiri atas pengetahuan, sikap, kepercayaan, status ekonomi keyakinan, nilai dan motivasi. faktor pemungkin adalah faktor yang memungkinkan atau memfasilitasi prilaku atau tindakan yang terdiri atas fasilitas kesehatan, sarana dan prasarana kesehatan dan peran Petugas kesehatan sedangkan faktor penguat adalah faktor-faktor yang mendorong atau memperkuat terjadinya perilaku yang terdiri atas tokoh agama, Masyarakat, peran keluarga, peraturan, lingkungan, sikap petugas kesehatan, Undang-Undang dan surat keputusan.

Berdasarkan teori perilaku kesehatan tersebut penulis ingin meneliti hal yang mempengaruhi seseorang dalam melakukan HPV (Human Papilloma Virus) untuk mengetahui hubungan pengetahuan, status ekonomi, peran petugas, dan peran keluarga terhadap HPV (Human Papilloma Virus).

\section{METODE PENELITIAN}

Penelitian ini bersifat deskriptif analitik dengan desain Cross Sectional yaitu variabel independen dan variabel dependen diukur pada saat yang sama. Tujuan penelitian ini untuk mengetahui hubungan pengetahuan, status ekonomi, peran petugas kesehatan dan peran keluarga terhadap vaksinasi HPV (Human Papilloma Virus) yang telah dilakukan pada bulan November tahun 2017 di Klinik Dara Jingga Kota Jambi (Notoadmojo, 2012).

Populasi adalah seluruh wanita yang datang ke klinik dara jingga yang berjumlah 321 orang dengan teknik pengambilan sampel yaitu acidental sampling dengan jumlah sampel 32 orang. Data diperoleh melalui pengisian kuesioner yang diberikan kepada responden. Data yang dikumpulkan telah di analisis secara univariat dan bivariat yang dibantu oleh program komputer.

\section{HASIL DAN PEMBAHASAN}

Analisis univariat

Gambaran Pemberian Vaksinasi di Klinik Dara Jingga Kota Jambi Tahun 2017

Tabel 1. Distribusi Responden

Berdasarkan Pemberian Vaksinasi HPV

(Human Papilloma Virus) di Klinik Dara Jingga Kota JambiTahun 2017

Pemberian

\begin{tabular}{lcc}
\multicolumn{1}{r}{ vaksinasi } & Jumlah & $\%$ \\
\hline Memanfaatkan & 10 & 31,3 \\
Tidak & 22 & 68,8 \\
memanfaatkan & 32 & 100 \\
\hline \multicolumn{1}{c}{ Total } &
\end{tabular}

Berdasarkan

tabel

1

menunjukkan bahwa yaitu sebanyak 10 responden $(31,3 \%)$ memanfaatkan vaksinasi HPV dan sebanyak 22 responden $(68,8 \%)$ tidak memanfaatkan vaksinasi HPV.

\section{Gambaran Pengetahuan Ibu Tentang Vaksinasi HPV di Klinik Dara Jingga Kota Jambi Tahun 2017}


Tabel 2. Distribusi Responden

Berdasarkan Pengetahuan Ibu Tentang

Vaksinasi HPV (Human Papilloma

Virus) di Klinik Dara Jingga Kota Jambi Tahun 2017

\begin{tabular}{|c|c|c|c|c|c|}
\hline \multicolumn{3}{|c|}{ Tahun 2017} & \multicolumn{3}{|c|}{ Dara Jingga Kota Jambi Tahun 2017} \\
\hline Pengetahuan & Jumlah & $\%$ & Peran petugas & & \\
\hline Baik & 5 & 15,6 & kesehatan & Jumlah & $\%$ \\
\hline Cukup & 15 & 46,9 & Baik & 13 & 40,6 \\
\hline Kurang baik & 12 & 37,5 & Kurang baik & 19 & 59,4 \\
\hline Total & 32 & 100 & Total & 32 & 100 \\
\hline
\end{tabular}

jawaban dari 32 responden yang telah diteliti mengenai vaksinasi HPV di Klinik Dara Jingga Kota Jambi, terdapat sebanyak 5 responden $(15,6 \%)$ memiliki pengetahuan baik, sebanyak 15 responden $(46,9 \%)$ memiliki pengetahuan cukup dan sebanyak 12 responden $(37,5 \%)$ memiliki pengetahuan kurang baik tentang vaksinasi HPV.

Gambaran Status Ekonomi Terhadap Vaksinasi HPV (Human Papilloma Virus) di Klinik Dara Jingga Kota Jambi Tahun 2017.

Tabel 3. Distribusi Responden

Berdasarkan Status Ekonomi di Klinik Dara Jingga Kota Jambi Tahun

\begin{tabular}{lcc}
\multicolumn{3}{c}{2017} \\
\hline Status ekonomi & Jumlah & $\%$ \\
\hline Tinggi & 13 & 40,6 \\
Rendah & 19 & 59,4 \\
\hline Total & 32 & 100 \\
\hline
\end{tabular}

Berdasarkan tabel

3 ,

menunjukkan bahwa yaitu sebanyak 13 responden $(40,6 \%)$ memiliki status ekonomi tinggi dan sebanyak 19 responden $(59,4 \%)$ memiliki status ekonomi rendah.

\footnotetext{
Gambaran Peran Petugas Kesehatan Terhadap Vaksinasi HPV (Human Papilloma Virus) di Klinik Dara Jingga Kota Jambi Tahun 2017
}

Tabel 4. Distribusi Responden

Berdasarkan PeranPetugas

KesehatanTerhadapVaksinasiHPV

(Human Papilloma Virus) di Klinik Dara Jingga Kota Jambi Tahun 2017

Berdasarkan data distribusi jawaban dari 32 responden yang telah diteliti mengenai peran petugas kesehatan terhadap vaksinasi HPV di Klinik Dara Jingga Kota Jambi, yaitu sebanyak 13 responden $(40,6 \%)$ memiliki peran petugas kesehatan baik dan sebanyak 19 responden $(59,4 \%)$ memiliki peran petugas kesehatan kurang baik.

\section{Gambaran Peran Keluarga \\ Terhadap Vaksinasi HPV (Human Papilloma Virus) di Klinik Dara Jingga Kota Jambi Tahun 2017}

Tabel 5. Distribusi Responden Berdasarkan Peran Keluarga Terhadap Vaksinasi HPV (Human Papilloma Virus) di Klinik Dara Jingga Kota Jambi Tahun 2017

\begin{tabular}{lcc}
\hline Peran keluarga & Jumlah & $\%$ \\
\hline Baik & 11 & 34,4 \\
Kurang baik & 21 & 56,6 \\
\hline Total & 32 & 100 \\
\hline
\end{tabular}

Berdasarkan data distribusi jawaban dari 32 responden yang telah diteliti mengenai peran keluarga terhadap vaksinasi HPV di Klinik Dara Jingga Kota Jambi, yaitu sebanyak 11 responden $(34,4 \%)$ memiliki peran keluarga baik dan sebanyak 21 responden $(65,6 \%)$ memiliki peran keluarga kurang baik.

\section{Analisis Bivariat}


Hubungan Pengetahuan Terhadap Vaksinasi HPV (Human Papilloma
Virus) di Klinik Dara Jingga Kota Jambi Tahun 2017

Tabel 6. Analisis Hubungan Pengetahuan Terhadap Vaksinasi HPV (Human Papilloma Virus) di Klinik Dara Jingga Kota Jambi Tahun 2017

\begin{tabular}{lccccccc}
\hline \multirow{2}{*}{ Pengetahuan } & \multicolumn{4}{c}{ Vaksin HPV } & & \multirow{2}{*}{ total } & $\begin{array}{c}\text { p- } \\
\text { value }\end{array}$ \\
\cline { 2 - 9 } & Tidak dimanfaatkan & \multicolumn{2}{c}{ Dimanfaatkan } & & & f \\
\cline { 2 - 8 } & $\mathrm{f}$ & $\%$ & $\mathrm{f}$ & $\%$ & $\mathrm{f}$ & $\%$ & \\
Kurang baik & 10 & 83,3 & 2 & 16,7 & 12 & 100 & \\
Cukup & 11 & 73,3 & 4 & 26,7 & 15 & 100 & 0,032 \\
Baik & 1 & 20 & 4 & 80 & 5 & 100 & \\
total & 22 & 68,8 & 10 & 31,2 & 32 & 100 & \\
\hline
\end{tabular}

Dari hasil 32 responden tentang pengetahuan terhadap vaksinasi HPV (Human Papilloma Virus) di Klinik Dara Jingga Kota Jambi, didapat dari 5 responden dengan pengetahuan baik yang tidak memanfaatkan vaksinasi HPV sebanyak 1 responden $(20,0 \%)$, dari 15 responden yang memiliki pengetahuan cukup sebanyak 11 responden $\quad(73,3 \%) \quad$ tidak memanfaatkan vaksinasi HPV. Sedangkan dari 12 responden dengan pengetahuan kurang baik didapat 10 responden $(83,3 \%) \quad$ tidak memanfaatkan vaksinasi HPV.

Tabel 7. Analisis Hubungan Status Ekonomi Terhadap Vaksinasi HPV (Human Papilloma Virus) di Klinik Dara Jingga Kota Jambi Tahun 2017

\begin{tabular}{|c|c|c|c|c|c|c|c|}
\hline \multirow{3}{*}{$\begin{array}{l}\text { Status } \\
\text { ekonomi }\end{array}$} & \multicolumn{4}{|c|}{ Vaksin HPV } & \multirow{2}{*}{\multicolumn{2}{|c|}{ total }} & \multirow{3}{*}{$\begin{array}{c}\mathrm{p}- \\
\text { value }\end{array}$} \\
\hline & \multicolumn{2}{|c|}{ Tidak dimanfaatkan } & \multicolumn{2}{|c|}{ Dimanfaatkan } & & & \\
\hline & $\mathrm{f}$ & $\%$ & $\mathrm{f}$ & $\%$ & $\mathrm{f}$ & $\%$ & \\
\hline Rendah & 17 & 89,5 & 2 & 10,5 & 19 & 100 & \\
\hline tinggi & 5 & 38,5 & 8 & 61,5 & 13 & 100 & 0,002 \\
\hline total & 22 & 68,8 & 10 & 31,2 & 32 & 100 & \\
\hline
\end{tabular}

Dari hasil 32 responden tentang status ekonomi terhadap vaksinasi HPV (Human Papilloma Virus) di Klinik Dara Jingga Kota Jambi, didapat dari 13 responden dengan status ekonomi tinggi yang tidak memanfaatkan vaksinasi HPV sebanyak 5 responden $(38,5 \%)$. Sedangkan dari 19 responden dengan status ekonomi rendah didapat 17 responden $\quad(89,5 \%) \quad$ tidak memanfaatkan vaksinasi HPV.
Dari hasil uji statistik chisquare diperoleh nilai $p$ value 0,032 $(\mathrm{p}<0,05)$ dengan demikian dapat disimpulkan bahwa ada hubungan antara pengetahuan ibu dengan vaksinasi HPV (Human Papilloma Virus) di Klinik Dara Jingga Kota Jambi.

\section{Hubungan Status Ekonomi Terhadap Vaksinasi HPV (Human Papilloma Virus) di Klinik Dara Jingga Kota Jambi Tahun 2017}




\section{Klinik Dara Jingga Kota Jambi Tahun 2017}

Tabel 8. Analisis Hubungan Peran Petugas KesehatanTerhadap Vaksinasi HPV (Human Papilloma Virus) di Klinik Dara Jingga Kota Jambi Tahun 2017

\begin{tabular}{lccccccc}
\hline \multirow{2}{*}{$\begin{array}{l}\text { Peran petugas } \\
\text { kesehatan }\end{array}$} & \multicolumn{4}{c}{ Vaksin HPV } & \multicolumn{2}{c}{ total } & \multirow{2}{*}{ p-value } \\
\cline { 2 - 7 } & $\mathrm{T}$ & $\%$ & $\mathrm{f}$ & $\%$ & $\mathrm{f}$ & $\%$ & \\
\hline Rendah & 17 & 89,5 & 2 & 10,5 & 19 & 100 & \\
tinggi & 5 & 38,5 & 8 & 61,5 & 13 & 100 & \multirow{2}{*}{0,002} \\
\cline { 1 - 8 } total & 22 & 68,8 & 10 & 31,2 & 32 & 100 & \\
\hline
\end{tabular}

Dari hasil 32 responden tentang peran petugas kesehatan terhadap vaksinasi HPV (Human Papilloma Virus) di Klinik Dara Jingga Kota Jambi, didapat dari 13 responden peran petugas kesehatan baik yang tidak memanfaatkan vaksinasi HPV sebanyak 5 responden $(38,5 \%)$. Sedangkan dari 19 responden dengan peran petugas kesehatan kurang baik didapat 17 responden $(89,5 \%)$ tidak memanfaatkan vaksinasi HPV.

Dari hasil uji statistik chisquare diperoleh nilai $p$ value 0,002 $(\mathrm{p}<0,05)$ dengan demikian dapat disimpulkan bahwa ada hubungan antara peran petugas kesehatan dengan vaksinasi HPV (Human Papilloma Virus) di Klinik Dara Jingga Kota Jambi.

\section{Hubungan Peran Keluarga Terhadap Vaksinasi HPV (Human Papilloma Virus) di Klinik Dara Jingga Kota Jambi Tahun 2017}

Tabel 9. Analisis Hubungan Peran Keluarga Terhadap Vaksinasi HPV (Human PapillomaVirus) di Klinik Dara Jingga Kota Jambi Tahun 2017

$$
\text { Vaksin HPV }
$$

\begin{tabular}{|c|c|c|c|c|c|c|c|}
\hline \multirow{3}{*}{ Peran keluarga } & \multicolumn{4}{|c|}{ Vaksin HPV } & \multirow{2}{*}{\multicolumn{2}{|c|}{ total }} & \multirow{3}{*}{$\mathrm{p}$-value } \\
\hline & \multicolumn{2}{|c|}{ Tidak dimanfaatkan } & \multicolumn{2}{|c|}{ Dimanfaatkan } & & & \\
\hline & $\mathrm{f}$ & $\%$ & $\mathrm{f}$ & $\%$ & $\mathrm{f}$ & $\%$ & \\
\hline Kurang baik & 18 & 85,7 & 3 & 14,3 & 21 & 100 & \multirow{3}{*}{0,004} \\
\hline Baik & 4 & 36,4 & 7 & 63,6 & 11 & 100 & \\
\hline total & 22 & 68,8 & 10 & 31,2 & 32 & 100 & \\
\hline
\end{tabular}

Dari hasil 32 responden tentang peran keluarga terhadap vaksinasi HPV (Human Papilloma Virus) di Klinik Dara Jingga Kota Jambi, didapat dari 11 responden peran keluarga baik yang tidak memanfaatkan vaksinasi HPV sebanyak 4 responden $(36,4 \%)$. Sedangkan dari 21 responden dengan peran keluarga kurang baik didapat 18 responden $(85,7 \%)$ tidak memanfaatkan vaksinasi HPV.

Penelitian ini sejalan dengan penelitian Kurniati (2012) mengenai hubungan pengetahuan dan peran keluarga teradap pemberian vaksinasi
HPV di Puskesmas Mergangsan, menunjukkan bahwa $80,9 \%$ tidak melakukan vaksinasi HPV.

Dari hasil uji statistik chisquare diperoleh nilai $p$ value 0,004 $(\mathrm{p}<0,05)$ dengan demikian dapat disimpulkan bahwa ada hubungan antara peran keluarga dengan vaksinasi HPV (Human Papilloma Virus) di Klinik Dara Jingga Kota Jambi.

\section{SIMPULAN}

Sebanyak 10 responden $(31,3 \%)$ memanfaatkan vaksinasi HPV dan sebanyak 22 responden 
$(68,8 \%)$ tidak memanfaatkan

vaksinasi HPV; Sebanyak 5 responden $\quad(15,6 \%) \quad$ memiliki

pengetahuan baik, sebanyak 15 responden $(46,9 \%)$ memiliki

pengetahuan cukup dan sebanyak 12 responden $(37,5 \%) \quad$ memiliki pengetahuan kurang baik tentang vaksinasi HPV; Sebanyak 13 responden $(40,6 \%)$ memiliki status ekonomi tinggidan sebanyak 19 responden $(59,4 \%)$ memiliki status ekonomi rendah; Sebanyak 13 responden $(40,6 \%)$ memiliki peran petugas kesehatan baik dan sebanyak 19 responden $(59,4 \%)$ memiliki peran petugas kesehatan kurang baik; Sebanyak 11 responden $(34,4 \%)$ memiliki peran keluarga baik dan sebanyak 21 responden $(65,6 \%)$ memiliki peran keluarga kurang baik; Adanya hubungan antara pengetahuan ibu dengan vaksinasi HPV (Human Papilloma Virus) di Klinik Dara Jingga Kota Jambinilai $p$ value 0,032 ; Adanya hubungan antara status ekonomi dengan vaksinasi HPV (Human Papilloma Virus) di Klinik Dara Jingga Kota Jambi dengan nilai $p$ value 0,002; Adanya hubungan antara peran petugas kesehatan dengan vaksinasi HPV (Human Papilloma Virus) di Klinik Dara Jingga Kota Jambi dengan nilai $p$ value 0,002; Adanya hubungan antara peran keluarga dengan vaksinasi HPV (Human Papilloma Virus) di Klinik Dara Jingga Kota Jambi dengan nilai $p$ value 0,004 .

\section{DAFTAR PUSTAKA}

Aminati, Dini, 2013. Cara Bijak Menghadapi Dan Mencegah Kanker Leher Rahim. Yogyakata : Brilliart Books.

Kemenkes RI, 2015. Pravelensi Kanker Serviks. Ebook
Kumalasari, Intan, 2012. Kesehatan Reproduksi. Jakarta : Salemba Medika.

Kurniati, 2012. Jurnal Penelitian Vaksinasi Human Pipilloma Virus Di Puskesmas Margangsan. Diunggah tanggal 25-06-2016.

Notoadmodjo, 2012. Metode Penelitian Kesehatan . Jakarta : Rineka Cipta

Purwoastuti, 2014.Panduan Menteri Kesehatan Reproduksi Dan Keluarga Berencana. Yogyakarta : Pustakabarukes.

Savitri, Astrid, 2015. Kupas Tuntas Kanker Payudara Leher Rahim Dan Rahim. Yogyakarta : Pustaka Baru Press.

Tilong, Adi. 2012. Bebas Dari Ancaman Kanker Serviks. Jogjakarta : Flashbooks.

Wijaya, Delia, 2010. Pembunuh Ganas Itu Kanker Serviks.Yogyakarta : Sinar Kejora.

Yayasan Kanker Indonesia, 2014.Buleten Kanker. Diunggah tanggal 25-06-2016.

Hubungan Pengetahuan, Status Ekonomi, Peran Petugas Kesehatan Dan Peran Keluarga Terhadap Vaksinasi Hpv (Human Papilloma Virus) Di Klinik Dara Jingga Kota Jambi Tahun 2017 